\title{
Piotr Konik*
}

\author{
DOPUSZCZALNOŚĆ UMOWNEJ REGULACJI \\ ODPOWIEDZIALNOŚCI INWESTORA \\ ZA ZAPLATE WYNAGRODZENIA \\ NALEŻNEGO PODWYKONAWCY \\ GENERALNEGO WYKONAWCY I JEJ ZAKRES
}

\begin{abstract}
Streszczenie
Artykuł dotyczy możliwości umownego kształtowania odpowiedzialności inwestora za zapłatę wynagrodzenia, należnego podwykonawcy generalnego wykonawcy robót budowlanych, co wynika z art. $647^{1} \S 5$ k.c. w brzmieniu obowiązującym do 1 czerwca 2017 r. Wprawdzie w art. $647^{1} \S 6$ k.c. wskazano, że odmienne postanowienia umowne są nieważne, ale z drugiej strony regulacja ustawowa jest bardzo ogólna, co rodzi pytanie choćby o możliwość jej doprecyzowania w umowie. Rozważania prowadzą do wniosku, że swoboda umów jest wąska i ogranicza się w zasadzie do kwestii rozliczeń pomiędzy generalnym wykonawcą a inwestorem, gdy ten ostatni dokona zapłaty na rzecz podwykonawcy. Umownie można także uregulować obowiązki informacyjne generalnego wykonawcy wobec inwestora w zakresie rozliczeń tego pierwszego z podwykonawcami.
\end{abstract}

Słowa kluczowe: odpowiedzialność inwestora za zapłatę wynagrodzenia należnego podwykonawcy, umowne kształtowanie odpowiedzialności inwestora, wynagrodzenie należne podwykonawcy robót budowlanych, zakres odpowiedzialności inwestora

* dr Piotr Konik, adiunkt w Katedrze Prawa Cywilnego Wydziału Prawa Uniwersytetu wBiałymstoku, e-mail: piotr.konik@elegis.pl 


\section{Wprowadzenie}

Kwestia odpowiedzialności inwestora za zapłatę wynagrodzenia należnego podwykonawcy generalnego wykonawcy (wykonawcy) robót budowlanych uregulowana $\mathrm{w}$ art. $647^{1}$ k.c. ${ }^{1} \mathrm{w}$ praktyce pojawia się bardzo często wskazując, że równie często podwykonawcy spotykają się z brakiem zapłaty należnego im wynagrodzenia. Spowodowane jest to niewypłacalnością generalnych wykonawców (wykonawców), co powoduje, że ciężar zapłaty wynagrodzenia dla podwykonawców spada właśnie na inwestorów i to mimo że zapłacili już obciążające ich wynagrodzenie dla wykonawcy, tj. dla swojego kontrahenta ${ }^{2}$. Może to zachęcać do zastanowienia nad możliwością umownego kształtowania tej problematyki tak, aby przynajmniej złagodzić dotkliwość tych konsekwencji.

Zwykle analiza ta kończy się na etapie wstępnym, a to z powodu dwóch wątpliwości, które są na tyle istotne, że czynią dalsze rozważania bezprzedmiotowymi. Ponieważ inwestora na gruncie omawianej regulacji postrzega się jako jedynie odpowiedzialnego za cudzy dług, a nie jako dłużnika ${ }^{3}$, w pierwszym rzędzie chodzi o wątpliwość, czy strony umownie mogą w ogóle regulować kwestię odpowiedzialności. Po drugie zaś (i nade wszystko), chodzi o art. $647^{1}$ $\S 6$ k.c., który wyraźnie reglamentuje umowną regulację zagadnień unormowanych w tym przepisie i to pod sankcją nieważności. To powoduje silne przeświadczenie, że materia ta $\mathrm{w}$ całej rozciągłości jest wyłączona $\mathrm{z}$ kompetencji normotwórczej stron. W konsekwencji, rozważania w tym zakresie są zarówno w orzecznictwie, jak i doktrynie, praktycznie niespotykane. Wbrew takiemu podejściu zagadnienie to wydaje się nie tak jednoznaczne i warto poświęcić mu więcej uwagi.

${ }^{1}$ Niniejsze opracowanie odnosi się do przepisu w brzmieniu obowiązującym do 1 czerwca 2017 r. Został on zmieniony ustawą z 7 kwietnia 2017 r. (Dz.U. poz. 933), która weszła w życie $\mathrm{z}$ dniem 1 czerwca $2017 \mathrm{r}$.

${ }^{2}$ Pogląd, że wcześniejsza zapłata przez inwestora wynagrodzenia na rzecz generalnego wykonawcy (wykonawcy) nie może być podstawą wyłączenia odpowiedzialności inwestora wobec podwykonawcy generalnego wykonawcy (wykonawcy) jest ugruntowany w orzecznictwie sądowym. Tak SN w wyroku z 5.09.2012 r., IV CSK 91/12, LEX nr 1275009; wyrok SN z 11.02.2016 r., V CSK 339/15, LEX nr 1977863.

${ }^{3}$ Wyrok SN z 10.12.2015 r., V CSK 95/15, LEX nr 1994372; wyrok SA w Białymstoku z 29.10.2015 r., I ACa 532/15, LEX nr 1927527; wyrok SA w Białymstoku z 22.07.2015 r., I ACa 270/15, LEX nr 1793797; P. Konik, Odpowiedzialność matżonków wspólników spótki cywilnejjako inwestora - wobec podwykonawców przy umowie o roboty budowlane, w: Status prawny matżonków w spótkach cywilnych $i$ handlowych, red. Z. Kuniewicz, K. Malinowska-Woźniak, Warszawa 2016, s. 156-157. 
Odnośnie do dopuszczalności umownego kształtowania odpowiedzialności, należy wskazać, że sformułowany został w doktrynie pogląd, iż kompetencja stron do umownego kształtowania zakresu odpowiedzialności jest generalnie wyłączona ${ }^{4}$. Niemniej trzeba podkreślić, że sama odpowiedzialność rozumiana jest na gruncie tej wypowiedzi wąsko, jako możliwość przymusowej realizacji obowiązków, a w szczególności jako możliwość wszczęcia postępowania sądowego, prowadzącego do wydania orzeczenia nakazującego zobowiązanemu podjęcie powinnego zachowania oraz możność wszczęcia następnie postępowania egzekucyjnego. Pogląd ten, wskazujący na przynależność wskazanego zagadnienia do problematyki stosunków procesowo-prawnych regulowanych prawem publicznym (procesowym), nie ma jednak większego znaczenia dla dalszych rozważań. W naszym przypadku chodzi bowiem nie o kwestię, jak od inwestora egzekwować należne podwykonawcy wynagrodzenie, ale o kształtowanie tego, kiedy i w jakim zakresie inwestor może być obarczony ciężarem wypłaty wynagrodzenia na rzecz podwykonawcy.

Odnośnie do drugiej wątpliwości należy podnieść, że w art. $647^{1} \S 6$ k.c. wskazuje się na imperatywny charakter norm (przepisów) zawartych w tym artykule na tyle wyraźnie, że w powszechnym przeświadczeniu nie zachodzi potrzeba szerszego omawiania tej kwestii. Stąd mało jest wypowiedzi na ten temat, a te które się spotyka, mają charakter prostych stwierdzeń, że chodzi o normy lub przepisy bezwzględnie obowiązujące czy ius $\operatorname{cogens} s^{5}$, albo też, że wprowadzanie zmian umownych byłoby nieważne ${ }^{6}$. Czasami można jednak spotkać stwierdzenia sugerujące pewne możliwości umownej ingerencji w tę problematykę, a co za tym idzie, także sferę objętą autonomią woli stron. Przykładowo, w wyroku z 5 listopada $2015 \mathrm{roku}^{7}$ SN wskazał, że:

umowa zawarta przez wykonawcę z podwykonawcą robót budowlanych nie może zawierać takich postanowień, które ograniczałyby możliwość zastosowania wynikającej z art. $647^{1} \S 5$ k.c. solidarnej odpowiedzialności inwestora i wykonawcy za zapłatę podwykonawcy wynagrodzenia za wykonane przez niego roboty budowlane.

${ }^{4}$ Tak P. Machnikowski, w: System Prawa Prywatnego, t. 5, Zobowiazania część ogólna, red. E. Łętowska, Warszawa 2006, s. 466.

${ }^{5}$ Na przykład wyrok SA w Białymstoku z 22.07.2015 r., I ACa 270/15, LEX 1793797.

${ }^{6}$ K. Zagrobelny, w: Kodeks cywilny. Komentarz, red. E. Gniewek, P. Machnikowski, Warszawa 2014, s. 1267.

${ }^{7}$ Wyrok SN z 5.11.2015 r., sygn V CSK 124/15, LEX nr 1846475. 
Może to stanowić sugestię, co do semiimperatywnego charakteru norm wynikających z art. $647^{1}$ k.c., a w konsekwencji, do dopuszczalności poszerzania zakresu odpowiedzialności inwestora. Sugestię tę może także wspierać powtarzany często motyw wprowadzenia tej regulacji, tj. potrzeba ochrony interesów podwykonawców, którzy nie otrzymują należnych im od kontrahentów wynagrodzeń za wykonane roboty. Wydaje się jednak, że przepis art. $647^{1} \S 6$ k.c. jest na tyle wyraźnie sformułowany, że brakuje podstaw do nadawania tej wypowiedzi ustawodawcy innego znaczenia, a zwłaszcza wskazującego, iż strony mogą, działając na korzyść podwykonawcy, rozszerzać zakres tej regulacji. Istotne jest także spostrzeżenie, że omawiana regulacja ma nie tylko chronić podwykonawców, ale także uwzględniać interes inwestora, na którego nakłada się przecież odpowiedzialność za cudzy dług. Ma więc ona zapewniać wyważenie interesów obu kategorii podmiotów, czemu służy usztywnienie tej regulacji przez nadanie jej charakteru imperatywnego, a w konsekwencji jej wyłączenie z zakresu możliwości umownego kształtowania.

Zauważyć jednak należy, że omawiana regulacja jest bardzo ogólna, a wiele zagadnień szczegółowych wydaje się być nieuregulowanych. To otwiera drogę do rozważań zmierzających do odpowiedzi na pytanie, czy z tego powodu strony nie mają jednak kompetencji do uregulowania kwestii nieuregulowanych, czy doprecyzowania tych, które nie są uregulowane szczegółowo. W mojej ocenie wymaga to jednak wnikliwej analizy poszczególnych zagadnień związanych z odpowiedzialnością inwestora, a zwłaszcza zweryfikowania, czy szczegóły konstrukcji tej odpowiedzialności nie dają się wyprowadzić z art. $647^{1} \S 1-5$ k.c. dzięki odpowiedniej interpretacji. Wydaje się, że zachodzić tu będzie pewna prawidłowość, a mianowicie, że im więcej kwestii będzie możliwych do ustalenia w ten sposób, tym bardziej owa regulacja będzie kompletna i zupełna, a w rezultacie - tym mniejsza będzie sfera dla potencjalnej swobody kontraktowej stron.

Dalsze rozważania dotyczyć będą poszczególnych zagadnień związanych z odpowiedzialnością inwestora za zapłatę wynagrodzenia należnego podwykonawcy, a mianowicie, przesłanek powstania tej odpowiedzialności, jej ram czasowych, jej przedmiotu (za co inwestor odpowiada), możliwych do podnoszenia przez inwestora zarzutów, rozliczeń po zaspokojeniu podwykonawcy przez inwestora oraz innych zagadnień związanych z odpowiedzialnością inwestora. Przy czym, w pierwszej kolejności zostanie przedstawiona analiza danego zagadnienia w celu oceny stanu i zakresu zupełności jego uregulowania, a następnie na tym tle zostaną przeprowadzone rozważania dotyczące ewentualnej 
dopuszczalności i zakresu swobody co do umownego jego kształtowania przez strony.

\section{Swoboda umownego kształtowania przesłanek odpowiedzialności inwestora}

Przyjmuje się, że, zgodnie z art. $647^{1} \S 2$ k.c., przesłanką niezbędną do powstania odpowiedzialności inwestora, o której mowa w $\S 5$ tego artykułu, jest zgoda inwestora na zawarcie przez generalnego wykonawcę (wykonawcę) umowy z podwykonawcą ${ }^{8}$.

Wprawdzie w art. $647^{1} \S 2$ zdaniu 2 k.c. ustawodawca reguluje także sposób wyrażania zgody przez inwestora, niemniej regulacja ta nie jest uznawana za wyczerpującą. W piśmiennictwie ${ }^{9}$, a zwłaszcza w orzecznictwie sądowym ${ }^{10}$ wskazuje się, że owa zgoda może być wyrażana w dwojaki sposób - bierny (pasywny) oraz czynny (aktywny). Przy czym, jak się podkreśla ${ }^{11}$ :

wyrażenie zgody w sposób bierny objawia się brakiem zgłoszenia na piśmie sprzeciwu lub zastrzeżeń w terminie 14 dni od przedstawienia mu przez wykonawcę umowy z podwykonawcą lub jej projektu, wraz z częścią dokumentacji dotyczącą wykonania robót określonych w umowie lub projekcie. (...) Drugi sposób wyrażenia zgody (czynny) może przybrać różną formę. Inwestor może wyrażać ją w sposób wyraźny pisemnie bądź ustnie albo poprzez inne zachowanie, które w sposób dostateczny ujawnia jego wolę (art. 60 k.c.). Może nastąpić to poprzez czynności faktyczne, w sposób dorozumiany, na przykład przez tolerowanie obecności podwykonawcy na placu budowy, dokonywanie wpisów w jego dzienniku budowy,

\footnotetext{
${ }^{8}$ Nie jest ona natomiast przesłanką ważności umowy zawartej pomiędzy generalnym wykonawcą a podwykonawcą. Umowa taka będzie ważna, ale nie zostanie wywołany skutek w postaci solidarnej odpowiedzialności inwestora za cudzy dług. Tak SN w wyroku z 18.06.2015 r., III CSK 370/14, LEX 1745820; K. Zagrobelny, Odpowiedzialność inwestora z umowy o roboty budowlane, Warszawa 2013, s. 222; M. Jamka, K. Orzechowski, Zgoda inwestora na umowe generalnego wykonawcy z podwykonawca, „Monitor Prawniczy” 2009, nr 17, s. 936.

${ }^{9}$ Zobacz szerzej K. Zagrobelny, Odpowiedzialność inwestora..., s. 225-238 i podana tam literatura; M. Jamka, K. Orzechowski, Zgoda inwestora...; J. Strzępka, Zgoda inwestora na zawarcie umowy o wykonawstwo, „Monitor Prawniczy” 2012, nr 21.

${ }^{10}$ Wyrok SN z 27.06.2013 r., III CSK 298/12, LEX nr 1365675; wyrok SN z 24.01.2014 r., V CSK 124/13, LEX nr 1428996.

${ }^{11}$ Wyrok SA w Szczecinie z 28.02.2013 r., I ACa 705/12, LEX nr 1344201.
} 
odbieranie wykonanych przez niego robót, oraz dokonywanie podobnych czynności.

Taki sposób rozumienia omawianej przesłanki i jej zakres pojęciowy jest już ugruntowany. W konsekwencji, ze względu na imperatywny charakter omawianej regulacji należy uznać, że strony nie mają kompetencji do tego, aby dokonać w tym zakresie modyfikacji umownej, prowadzącej do wyeliminowania lub złagodzenia tej przesłanki (co pogorszyłoby sytuację inwestora, ułatwiając powstanie jego odpowiedzialności), ale także do jej wzmocnienia lub wprowadzenia kolejnej przesłanki, uzależniającej powstanie odpowiedzialności inwestora od innej jeszcze okoliczności (co pogorszałoby sytuację podwykonawcy, ograniczając możliwość powstania odpowiedzialności inwestora). Z tego powodu za niedopuszczalne (a więc i za bezskuteczne) należałoby uznać także umowne próby określenia postaci zgody inwestora, w szczególności wyłączając możliwość wyrażenia tej zgody w określony sposób, dopuszczalny obecnie w wyniku czynności interpretacyjnych, podejmowanych w doktrynie i orzecznictwie. Wydaje się jednak, że nie powinno to wyłączać możliwości doprecyzowania kwestii technicznych czy formalnych związanych z występowaniem o wyrażenie zgody czy informowaniem o jej udzieleniu lub jej braku. Regulacje te nie moga jednak rzutować w żadnym razie na zakres omawianej przesłanki, a zwłaszcza ułatwiać lub utrudniać powstawania odpowiedzialności inwestora.

Przy zgodzie inwestora pojawia się także kwestia, kiedy może być ona wyrażona. Przy czym wątpliwości raczej nie budzi kwestia momentu początkowego (za ten bowiem uważa się zawarcie umowy głównej ${ }^{12}$ ), ale momentu końcowego. Artykuł $647^{1}$ k.c. tego nie precyzuje, wskazano w nim jedynie, że zgoda ma dotyczyć zawarcia umowy z podwykonawcą, co mogłoby wskazywać, że chodzi o jej wyrażenie przed zawarciem takiej umowy ${ }^{13}$. W orzecznictwie przyjęto jednak wykładnię liberalną, opartą na możliwości wyrażenia tej zgody przez inwestora także ex post ${ }^{14}$, tj. już po zawarciu umowy podwykonawczej, co zresztą jest sytuacją bardzo częstą. Podobny pogląd spotykany jest w doktrynie ${ }^{15}$, gdzie

12 E. Strzępka-Frania, Umowy o generalne wykonawstwo robót budowlanych, Warszawa 2010, s. 248.

13 Trzeba wskazać, że właściwie pomija się kwestię momentu.

${ }^{14}$ Na przykład wyrok SA w Krakowie z 18.12.2015 r., I ACa 1286/15, LEX 1999302 czy wyrok SN z 18.06.2015 r., III CSK 370/14, LEX 1745820 i przywoływane tam orzecznictwo.

${ }^{15} \mathrm{~K}$. Zagrobelny, Odpowiedzialność inwestora..., s. 238-239. 
zaznaczono także, że może to nastąpić zarówno przed rozpoczęciem prac, jak i w toku ich wykonywania, ale raczej nie po ich zakończeniu ${ }^{16}$. W judykaturze brakuje jednak zgodności co do tego, do jakiego momentu najpóźniej zgoda w ogóle może być wyrażona. Został sformułowany pogląd, że ten moment nie może być dowolny, a w szczególności nie może on być oderwany od momentu zawarcia umowy podwykonawczej, rozpoczęcia prac przez podwykonawcę czy odbioru jego robót ${ }^{17}$. Pojawił się także pogląd odmienny, wskazujący, że może to być dowolny czas, a więc nawet i po wykonaniu robót przez podwykonaw$c^{18}{ }^{18}$. Przy czym pierwszy odwołuje się do wykładni funkcjonalnej i nakazuje brać pod uwage cel wprowadzenia omawianej regulacji (i z tego wywodzi sformułowany wniosek), natomiast drugi ogranicza się wyłącznie do wniosków płynących z wykładni gramatycznej i kluczowego stwierdzenia, że sam przepis żadnego ograniczenia w tym zakresie nie formułuje.

Wydaje się jednak, że można sformułować wniosek, iż ustawodawca przez takie ukształtowanie omawianego przepisu określił ten element konstrukcyjny odpowiedzialności inwestora bardzo szeroko, właśnie przewidując, że dla wyrażenia zgody możliwy jest każdy moment, niezależny także od wykonania robót przez podwykonawcę. W rezultacie kwestia ta nie może uchodzić za nieuregulowaną, a co za tym idzie, strony w umowie nie mogą tego skutecznie ukształtować odmiennie. Każda taka zmiana oznaczałaby bowiem ograniczenie ram czasowych tej konstrukcji.

\section{Swoboda umownego ksztaltowania czasu uaktualnienia się odpowiedzialności inwestora}

Przepis art. $647^{1}$ k.c. nie określa expressis verbis, kiedy uaktualnia się odpowiedzialność inwestora, co przy przyjęciu, że zagadnienie to leży poza zakresem jego regulacji, mogłoby prowadzić do wniosku o możliwości regulowania go umownie przez strony. Należy jednak wskazać, że przepis ten został

${ }^{16}$ P. Drapała, Glosa do wyroku SN z 6.10.2010 r., II CSK 210/10, OSP 2012, nr 5, poz. 48, s. 317.

${ }^{17}$ Wyrok SA w Gdańsku z 10.07.2015 r., I ACa 192/15, LEX nr 1927721.

${ }^{18}$ Wyrok SA w Krakowie z 28.04.2015 r., I ACa 197/15, LEX nr 1711716, w którym stwierdzono, że „Przepis art. $647^{1}$ k.c. nie określa terminu, w którym zgoda na zawarcie umowy z podwykonawcą może być wyrażona, a więc może to nastąpić także po wykonaniu prac przez podwykonawcę". 
poddano interpretacjom, które ostatecznie doprowadziły do ustalenia tej kwestii. W orzecznictwie sformułowano mianowicie tezę, że:

odpowiedzialność inwestora wobec podwykonawcy robót budowlanych na podstawie art. $647^{1} \S 5$ k.c. wymaga w pierwszej kolejności stwierdzenia odpowiedzialności wykonawcy robót wobec podwykonawcy, skoro odpowiedzialność inwestora ma charakter gwarancyjny ${ }^{19}$.

Najprościej rzecz ujmując, odpowiedzialność inwestora jako ponoszącego odpowiedzialność za cudzy dług ${ }^{20}$ pojawia się więc wraz z odpowiedzialnością po stronie generalnego wykonawcy (wykonawcy), jako dłużnika podwykonawcy co do zapłaty wynagrodzenia. Jeżeli odpowiedzialność rozumieć jako negatywne konsekwencje naruszenia zobowiązania przez dłużnika ${ }^{21}$, to należałoby przyjąć, że aktualizuje się ona konkretnie wtedy, gdy nadszedł już moment wykonania zobowiązania przez dłużnika (czyli w omawianym przypadku termin zapłaty wynagrodzenia), a świadczenie to nie zostało spełnione przez niego. Przy czym, skoro mamy do czynienia z odpowiedzialnością za cudzy dług, to dla oceny terminu zapłaty wynagrodzenia i jego wymagalności znaczenie ma wyłącznie treść zobowiązania łączącego wykonawcę z podwykonawcą 22 , a nie treść zobowiązania pomiędzy inwestorem a generalnym wykonawcą (wykonawcą). Można więc powiedzieć, że ramy odpowiedzialności inwestora wobec podwykonawcy określa umowa wykonawcy z podwykonawcą ${ }^{23}$. Przy braku zapłaty wynagrodzenia przez generalnego wykonawcę (wykonawcę) pojawia się podstawowa

${ }^{19}$ Wyrok SN z 11.07.2014 r., III CSK 245/13, LEX nr 1537292.

${ }^{20}$ Wyrok SN z 18.02.2016 r., II CSK 215/15, LEX nr 2023925; wyrok SN z 14.01.2016 r., IV CSK 179/15, LEX 1977037; wyrok SN z 17.02.2011 r., IV CSK 293/10, LEX 1111016; uchwała (7) SN z 29.04.2008 r., III CZP6/08, OSNC 2008, nr 11, poz. 121.

${ }^{21}$ Uzasadnieniem dla tego poglądu może być wypowiedź T. Dybowski, w: System prawa cywilnego, t. 3, cz. 1, Zobowiązania - część ogólna, red. S. Grzybowski, Wrocław-WarszawaKraków-Gdańsk 1976, s. 166.

${ }^{22} \mathrm{~W}$ treści zobowiązania kwestia terminu i przesłanek zapłaty wynagrodzenia (jego wymagalności) może być ujęta różnorodnie, w szczególności wynagrodzenie może być płatne częściami lub jednorazowo po wykonaniu całości robót.

${ }^{23}$ Wyrok SN z 16.04.2014 r., V CSK 296/13, LEX nr 1480194, a także wyrok SA w Łodzi z 13.08.2013 r., I ACa 286/13, LEX nr 1363282, w którym stwierdzono, że „odpowiedzialność inwestora wobec wykonawcy wynika z zawartej umowy o roboty budowlane i ta umowa określa zakres tej odpowiedzialności, natomiast odpowiedzialność inwestora wobec podwykonawców wynika z ustawy, ma charakter gwarancyjny, a jej ramy określa umowa wykonawcy z podwykonawcą, a nie zakres odpowiedzialności inwestora wobec wykonawcy". Nie musi to być przy tym uzależnione od odbioru robót pomiędzy generalnym wykonawcą (wykonawcą) a podwykonawcą, 
konsekwencja prawna, a mianowicie po stronie wierzyciela (podwykonawcy) powstaje możliwość przymusowego dochodzenia od dłużnika spełnienia świadczenia przed sądem i organem egzekucyjnym, a po stronie odpowiedzialnego - konieczność znoszenia tego przymusu. Dopiero wtedy powstaje także solidarność i możliwość decydowania przez wierzyciela, od kogo będzie dochodził zapłaty - od dłużnika, od odpowiedzialnego inwestora, czy też od obu łącznie.

Z powyższego wynika, że moment uaktualnienia się odpowiedzialności inwestora daje się wyprowadzić $\mathrm{z}$ art. $647^{1} \S 5$ k.c., a także, że zależny jest on wyłącznie od powstania odpowiedzialności po stronie generalnego wykonawcy (wykonawcy) i nie zależy od żadnych dodatkowych przesłanek. W konsekwencji, strony nie mają kompetencji do odmiennego uregulowania tej kwestii umownie. Nie mogą więc zmienić momentu uaktualnienia się tej odpowiedzialności - ani wskazując inny termin, ani formułując dodatkowe przesłanki. W szczególności nie mogą jej uzależnić od tego, czy w stosunku pomiędzy inwestorem i generalnym wykonawcą (wykonawcą) doszło już do odbioru robót, a także, czy powstał już po jego stronie obowiązek zapłaty wynagrodzenia na rzecz generalnego wykonawcy (wykonawcy), bądź jego odpowiedzialność wobec tego podmiotu z tytułu zapłaty tego wynagrodzenia ${ }^{24}$.

Odpowiedzialność inwestora, jako zależna od odpowiedzialności generalnego wykonawcy (wykonawcy) w zasadzie trwa tak długo, jak długo utrzymuje się odpowiedzialność (a w zasadzie dług) dłużnika. Także w tym zakresie stronom nie przysługuje swoboda co do wprowadzenia modyfikacji, a zwłaszcza skrócenia tego okresu.

Wydaje się jednak, że pewien zakres swobody przysługuje stronom w omawianej kwestii, a mianowicie co do warunków i czasu odpowiedzialności generalnego wykonawcy (wykonawcy) za zapłatę wynagrodzenia podwykonawcy. Inwestor w umowie z generalnym wykonawcą (wykonawcą) może określić przesłanki i warunki płatności wynagrodzenia dla ewentualnych podwykonawców, które generalny wykonawca (wykonawca) będzie miał obowiązek zamieścić w zawieranej przez siebie umowie podwykonawczej. W ten sposób pośrednio zaistnieje możliwość oddziaływania na moment aktualizacji odpowiedzialności

na co wskazuje wyrok SA w Warszawie z 19.01.2016 r., VI ACa 1388/15, LEX nr 2008293. W doktrynie K. Zagrobelny, Odpowiedzialność inwestora..., s. 245.

${ }^{24}$ Pogląd, że na te okoliczności inwestor nie może się powoływać na podstawie art. $647^{1}$ k.c. formułowany jest w orzecznictwie, zob. wyrok SA w Łodzi z 13.08.2013 r., I ACa 286/13, LEX nr 1363282. 
inwestora. Kwestia ta nie jest jednak objęta zupełną (nieograniczoną) swobodą, na co wskazuje choćby orzecznictwo poświęcone zagadnieniu wymagalności roszczenia o zapłatę wynagrodzenia przy robotach budowlanych. W konsekwencji, każde zbytnie odwlekanie w czasie momentu tej wymagalności po spełnieniu świadczenia przez podwykonawcę może rodzić wątpliwości co do jej skuteczności, a tym samym planowane przez inwestora przesunięcie w czasie momentu uaktualnienia się odpowiedzialności może się nie powieść i odpowiedzialność ta może zaktualizować się wcześniej.

\section{Swoboda umownego ksztaltowania zakresu przedmiotowego odpowiedzialności inwestora}

Odpowiedzialność inwestora ma zakres ograniczony. Wynika to z brzmienia art. $647^{1} \S 5$ k.c., w którym wskazano wyraźnie, że jest ona związana z wynagrodzeniem należnym podwykonawcy od generalnego wykonawcy (wykonawcy), a więc wynikającym ze stosunku zobowiązaniowego pomiędzy tymi podmiotami. Mając to na uwadze, formułuje się pogląd, że inwestor odpowiada tylko za to wynagrodzenie, a nie za inne elementy zobowiązania, w tym w szczególności, za odsetki za opóźnienie ${ }^{25}$. W orzecznictwie sądowym pojawia się wprawdzie kwestia odsetek za opóźnienie w zapłacie wynagrodzenia obciążających inwestora ${ }^{26}$, wydaje się jednak, że nie jest to wyrazem poglądu, iż odpowiedzialność inwestora obejmuje także odsetki za opóźnienie jako konsekwencję braku zapłaty przez wykonawcę wynagrodzenia dla podwykonawcy, ale że

${ }^{25}$ Zobacz, np. J. Strzępka, Zgoda inwestora na zawarcie umowy o wykonawstwo, „Monitor Prawniczy” 2012, nr 21, s. 1132; K. Zagrobelny, Odpowiedzialność inwestora..., s. 243. Pogląd taki formułowany jest także expressis verbis w orzecznictwie SN, zob. wyrok SN z 5.09.2012 r., IV CSK 91/12, LEX nr 1275009.

${ }^{26}$ Wyrok SN z 5.09.2012 r., IV CSK 91/12, LEX nr 1275009; wyrok SA w Katowicach z 27.02.2014 r., V ACa 746/13, LEX nr 1448538. Podkreśla się w nich, że zakres przedmiotowy odpowiedzialności inwestora ograniczony jest do wynagrodzenia należnego wykonawcy, czyli należności głównej, i nie obejmuje odsetek za opóźnienie, powstałych po stronie wykonawcy, ale ponieważ zobowiązanie inwestora wobec podwykonawcy do zapłaty wynagrodzenia za roboty budowlane wykonane przez podwykonawcę, co do zasady, ma charakter bezterminowy, w konsekwencji - zgodnie z art. 455 k.c. - termin jego spełnienia przez inwestora wyznacza skierowane do niego wezwanie do zapłaty. 
jest to konsekwencja osobista inwestora za to, że nie zaspokoił podwykonawcy niezwłocznie po wezwaniu go do zapłaty. Można jednak spotkać także pogląd odmienny ${ }^{27}$.

Odnośnie do samego wynagrodzenia, jego charakter i rozmiar wynika każdorazowo z umowy zawartej pomiędzy wykonawcą i podwykonawcą ${ }^{28}$. Trzeba jednak dodać, że nie chodzi o każdorazowe wynagrodzenie, ale o to ustalone w umowie, na której zawarcie zgodę wyraził inwestor, ewentualnie w wysokości zmienionej za zgodą inwestora ${ }^{29}$. W orzecznictwie przyjęto jednak rozszerzająco, że solidarna odpowiedzialność inwestora obejmuje także wynagrodzenie w wysokości ustalonej przez sąd na podstawie art. $632 \S 2$ k.c. ${ }^{30}$

Odpowiedzialność inwestora obejmuje wynagrodzenie niezależnie od tego, z jakiej umowy podwykonawczej wynika obowiązek jego zapłaty ${ }^{31}$. Sąd Najwyższy właściwie wskazał, że ,umowa wykonawcy z podwykonawcą może mieć charakter umowy o roboty budowlane albo umowy o dzieło, zależnie od zakresu powierzonych mu zadań" ${ }^{2}$, a istotne jest to, czy przedmiot mowy podwykonawczej wchodzi w skład obiektu, do którego wykonania zobowiązał się

${ }^{27}$ Zobacz wyrok SA w Łodzi z 21.04.2016 r., I ACa 1548/15, LEX 2053925, w którego uzasadnieniu stwierdza się, że „ochronna funkcja art. $647^{1} \S 5$ k.c. przemawia za objęciem odpowiedzialnością solidarną również ubocznego długu w postaci odsetek, skoro inwestor, wyrażając zgodę na zawarcie przez wykonawcę umowy z podwykonawcą, przyjmuje ustawową odpowiedzialność solidarną za dług ukształtowany tą umową, również w zakresie terminów płatności”. Możliwość takiej interpretacji jest także wskazywana w doktrynie. Tak P. Konik, Odpowiedzialność matżonków..., s. 160-161. Stanowisko to oparte jest na wywiedzeniu konsekwencji z tego, że inwestor ponosi odpowiedzialność za cudzy dług, jego sytuacja jest więc pochodną sytuacji generalnego wykonawcy (wykonawcy), a konsekwencją opóźnienia - jako jednym z elementów odpowiedzialności - z zapłatą wynagrodzenia dla podwykonawcy może być także obowiązek zapłaty odsetek za opóźnienie. Treść art. $647^{1} \S 5$ k.c. odwołującego się do wynagrodzenia nie musi stać temu na przeszkodzie, przepis ten nie mówi bowiem, że odpowiedzialność inwestora ograniczona jest tylko do wynagrodzenia, ale że jest to odpowiedzialność za zapłatę wynagrodzenia.

${ }^{28}$ K. Zagrobelny, Odpowiedzialność inwestora..., s. 244.

${ }^{29}$ Ibidem, s. 248; B. Kostecki, Uwagi na temat wyktadni przepisu art. 647 (1) Kodeksu cywilnego, „Przegląd Ustawodawstwa Gospodarczego” 2004, nr 7, s. 22.

${ }^{30}$ Wyrok SA w Gdańsku z 26.07.2013 r., I ACa 253/13, LEX nr 1362679.

${ }^{31}$ A. Damasiewicz, Umowa o roboty budowlane, Warszawa 2010, s. 255 i powołana tam literatura; K. Zagrobelny, Odpowiedzialność inwestora..., s. 244; W. Białończyk, Z problematyki umów o podwykonawstwo robót budowlanych, „Monitor Prawniczy” 2008, nr 4, s. 183; odmiennie P. Drapała, Umowa o roboty budowlane, „Przegląd Prawa Handlowego” 2003, nr 8, s. 14; M. Gutowski, Odpowiedzialność inwestora w umowach o roboty budowlane (na tle art. $647^{1}$ $\S 5$ k.c.), PiP 2008, z. 2, s. 80.

32 Wyrok SN z 21.08.2014 r., IV CSK 733/13, LEX nr 1541191. 
wobec inwestora wykonawca ${ }^{33}$. W konsekwencji należy przyjąć, że ustawodawca ujmuje tę kwestię szeroko.

W tych ramach inwestor odpowiada za całe wynagrodzenie i strony nie mogą ustalić tej kwestii umownie inaczej. W szczególności nie mogą przyjąć, że inwestor byłby odpowiedzialny za każdorazowe wynagrodzenie (niezależnie od tego, czy na zmianę wyraził zgodę), ani też, że odpowiedzialność ta będzie się ograniczać do jakiejś jego części (np. jednej z rat, określonego procentu czy limitu kwotowego) z góry określonej w umowie albo ustalonej samodzielnie przez inwestora albo, że będzie się ograniczała tylko do wynagrodzenia wynikającego $\mathrm{z}$ umowy określonego typu (np. tylko umowy o roboty budowlane). Podobnie należy ocenić objęcie odpowiedzialnością innych niż wynagrodzenie elementów, a w szczególności odszkodowania czy kar umownych.

\section{Umowna swoboda ksztaltowania problematyki rozliczeń pomiędzy inwestorem a generalnym wykonawcą (wykonawcą)}

Sytuacja inwestora i generalnego wykonawcy (wykonawcy) po zaspokojeniu podwykonawcy przez inwestora nie jest uregulowana w art. $647^{1}$ k.c. Próby jej sprecyzowania prowadzą w orzecznictwie do rozbieżnych wniosków. W pierwszej kolejności można wskazać na koncepcję, wedle której do rozliczeń w takiej sytuacji należy stosować art. $376 \S 1$ k.c. ${ }^{34}$ Stosownie zaś do jego treści, w przypadku, gdy stosunek prawny pomiędzy inwestorem a generalnym wykonawcą (wykonawcą) tego nie rozstrzyga, ten, który spełnił świadczenie, może żądać zwrotu w częściach równych. Oznaczałoby to, że inwestora obciążałaby ostatecznie odpowiednia część (w zależności od liczby współodpowiedzialnych) świadczenia spełnionego na rzecz podwykonawcy. W orzecznictwie pojawiło się także odmienne stanowisko, wedle którego w omawianej sytuacji stosowany powinien być art. 518 k.c. ${ }^{35}$. Oznacza to, że inwestor, zaspokajając podwykonawcę, wstępuje w miejsce zaspokojonego wierzyciela, zyskując wierzytelność wobec generalnego wykonawcy (wykonawcy). W konsekwencji, może on żądać

${ }^{33}$ Wyrok SN z 17.10.2008 r., I CSK 106/08, OSP 2010, nr 9, poz. 92.

${ }^{34}$ Wyrok SN z 11.02.2016 r., V CSK 339/15, LEX nr 1977863.

${ }^{35}$ Wyrok SA w Białymstoku, z 17.06.2015 r., I ACa 76/15, LEX nr 1755136, w którym wskazano, że „Zapłata przez inwestora wynagrodzenia podwykonawcy stanowi zaspokojenie cudzego długu i w takim wypadku stosuje się rozwiązanie przewidziane art. 518 k.c., a nie art. 376 $\S 1$ k.c.”; zob. też wyrok SA w Warszawie z 24.02.2015 r., I ACa 1240/14, LEX 1659147. 
od niego całości wypłaconej podwykonawcy kwoty i nie zostaje obciążony jakąkolwiek jej częścią.

Nie wdając się w szczegółowe rozważania, wydaje się, że bardziej prawidłowe jest stanowisko drugie. Przede wszystkim uwzględnia ono charakter odpowiedzialności inwestora, a zwłaszcza to, że jest on jedynie podmiotem odpowiedzialnym za cudzy dług solidarnie z dłużnikiem, samemu przy tym nie stając się dłużnikiem podwykonawcy. Okoliczność tę pomija zupełnie pierwsza koncepcja, traktując inwestora jak dłużnika. Artykuł 376 k.c. dość wyraźnie nie przystaje do sytuacji pomiędzy inwestorem a generalnym wykonawcą (wykonawcą), podobnie zresztą jak konsekwencje, które płyną z jego zastosowania. Trudno bowiem, moim zdaniem, znaleźć uzasadnienie, dla którego inwestor miałby ponosić w części ciężar spełnionego na rzecz podwykonawcy świadczenia, zwłaszcza, gdy wcześniej wypłacił już wynagrodzenie swemu kontrahentowi, który nie rozliczył się jednak ze swoimi kontrahentami.

Powyższe wątpliwości skłaniają do wyraźnego uregulowania tej kwestii przez zainteresowanych $\mathrm{w}$ umowie. $\mathrm{W}$ przeciwieństwie do zagadnień przedstawianych wcześniej, a nieuregulowanych wprost $\mathrm{w}$ art. $647^{1}$ k.c., omawiana kwestia może być oceniana odmiennie, tj. jako leżąca poza regulacją powołanego przepisu. Istotne wydaje się spostrzeżenie, że wraz z zaspokojeniem podwykonawcy zostaje zrealizowany cel tej regulacji, a jej zakres wyczerpany. Brak wyraźnej regulacji rozliczeń pomiędzy inwestorem i generalnym wykonawcą (podwykonawcą) powoduje więc „wysunięcie” tego zagadnienia poza zakres art. $647^{1}$ k.c., a więc także i jego $\S 6$. W konsekwencji należy uznać, że zagadnienie to może być przedmiotem regulacji umownych stron, które mogą precyzyjnie uregulować sposób zwrotu spełnionego przez inwestora świadczenia (terminy, kwoty) lub przewidzieć potrącenie $\mathrm{z}$ określonymi zobowiązaniami inwestora. Rozwiązania mogą być różne, zależnie przede wszystkim od tego, czy inwestor swoje świadczenie (wynagrodzenie) wobec generalnego wykonawcy (wykonawcy) już spełnił, czy też nie. 


\section{Swoboda umownego ksztaltowania problematyki zarzutów inwestora wobec podwykonawcy}

Ustawodawca expressis verbis nie reguluje w art. $647^{1}$ k.c. kwestii zarzutów podnoszonych przez inwestora. W orzecznictwie ${ }^{36} \mathrm{i}_{\text {doktrynie }}{ }^{37} \mathrm{jest}_{\text {ona jednak }}$ postrzegana przez pryzmat solidarności i w konsekwencji generalnie rozpatrywana na gruncie art. $375 \S 1$ k.c., który daje możliwość podnoszenia zarzutów osobistych przysługujących inwestorowi wobec podwykonawcy oraz zarzutów wspólnych - ze względu na sposób powstania lub treść zobowiązania - dla niego i dla generalnego wykonawcy (wykonawcy). Z tego zakresu wyłączane są wyraźnie zarzuty oparte na okolicznościach ze stosunku pomiędzy inwestorem a generalnym wykonawcą (wykonawcą), jak np. zarzut zapłaty wynagrodzenia przez inwestora na rzecz swego kontrahenta ${ }^{38}$, a także te zarzuty, które są powiązane z czynnościami prawnymi, których dokonać może tylko generalny wykonawca (wykonawca) jako strona stosunku prawnego łączącego go z podwykonawcą (np. potrącenie) ${ }^{39}$, a które nie zostały przez uprawnionego dokonane.

Wydaje się, że kwestia okoliczności możliwych do podnoszenia przez inwestora celem wyłączenia lub ograniczenia swojej odpowiedzialności jest tak ściśle powiązana z charakterem odpowiedzialności inwestora (solidarność oraz charakter gwarancyjny), że próba regulacji umownej tego zagadnienia musiałaby godzić w samą istotę tej odpowiedzialności wpływając na to, czy inwestor odpowiedzialnością tą byłby obarczony, czy nie. $Z$ tego powodu należy ją uznać za leżącą poza zakresem swobody kontraktowej stron.

${ }^{36}$ Wyrok SA w Rzeszowie z 27.02.2014 r., I ACa 467/13, LEX nr 1474764; wyrok SN z 18.02.2016 r., II CSK 215/15, LEX nr 2023925.

${ }^{37}$ Szerzej na ten temat P. Konik, Dopuszczalne zarzuty inwestora ponoszacego odpowiedzialność na podstawie art. $647^{1}$ \& 5 k.c. - glosa do wyroku Sadu Najwyższego z 18.02.2016 r., II CSK 215/15, „Glosa” 2017, nr 3, s. 80 i nast.

${ }^{38}$ Wyrok SN z 5.09.2012 r., IV CSK 91/12, LEX nr 1275009; wyrok SA w Katowicach z 27.02.2014 r., V ACa 746/13, LEX nr 1448538.

39 Wyrok SN z 18.02.2016 r., II CSK 215/15, LEX nr 2023925; wyrok SN z 5.09.2012 r., IV CSK 91/12, LEX 1275009. 


\section{Swoboda umownego kształtowania innych zagadnień związanych z odpowiedzialnością inwestora}

Do zagadnień, które ewidentnie mogą być regulowane umownie, można zaliczyć natomiast zagadnienia informacyjne pomiędzy inwestorem i generalnym wykonawcą (wykonawcą), dotyczące podwykonawców, a zwłaszcza rozliczeń z nimi. Inwestor, mając odpowiednie dane dotyczące stanu tych rozliczeń, a zwłaszcza wiedzę o terminach płatności wynagrodzeń na rzecz podwykonawców, czy o braku zapłaty, może dopasowywać swoje zachowania, a w szczególności rozliczenia z generalnym wykonawcą (wykonawcą) tak, aby nie dopuścić do powstania sytuacji, w której musi on dokonywać zapłaty na rzecz podwykonawcy, mimo że wcześniej zapłacił już wynagrodzenie w całości swemu kontrahentowi, albo zapewnić sobie możliwość przekierowania całości lub części wynagrodzenia należnego generalnemu wykonawcy (wykonawcy) na rzecz podwykonawcy ${ }^{40}$. Za dopuszczalną należy więc uznać regulację umowną, przewidującą generalnemu wykonawcy (wykonawcy) obowiązek przekazywania $\mathrm{w}$ odpowiedniej formie informacji o terminach płatności wynagrodzeń dla podwykonawców i stanie rozliczeń z nimi (np. pisemne wykazy rozliczeń z podwykonawcami), czy też obowiązek przekazywania inwestorowi oświadczeń podwykonawców co do stanu rozliczeń, a w szczególności, co do braku zaległości w tych rozliczeniach. Dla efektywności tej regulacji powinna ona być powiązana $\mathrm{z}$ uprawnieniami inwestora co do powstrzymania się z zapłatą na rzecz swego kontrahenta do czasu weryfikacji przekazywanych informacji, czy co do możliwości bezpośredniej zapłaty na rzecz podwykonawcy ze skutkiem w rozliczeniach z generalnym wykonawcą (wykonawcą).

\section{Podsumowanie}

Powyższe rozważania prowadzą do wniosku, że większość kwestii związanych z konstrukcją odpowiedzialności inwestora za zapłatę wynagrodzenia dla podwykonawcy, które nie są wyraźnie uregulowane w art. $647^{1}$ k.c., jak w szczególności ramy czasowe odpowiedzialności inwestora i moment uaktualnienia się tej odpowiedzialności, zakres zarzutów możliwych do podnoszenia

${ }^{40} \mathrm{Na}$ możliwość ograniczania ryzyka przez inwestora w tej sferze zwraca także uwagę A. Damasiewicz, Umowa o roboty budowlane..., s. 254. 
przez inwestora, są ustalane w drodze interpretacji, a co za tym idzie, nie mogą być uznane za nieobjęte regulacją przywołanego przepisu. W konsekwencji, odnosi się do nich sankcja z $\S 6$ i są one wyłączone z zakresu swobody kontraktowej stron. Regulacja art. $647^{1}$ k.c. nie jest jednak zupełna, a poza jej zakresem pozostaje kwestia rozliczeń związanych z zaspokojeniem podwykonawcy przez inwestora, a także kwestia obowiązków informacyjnych wobec inwestora. $\mathrm{W}$ tej sferze strony mogą więc tworzyć skuteczne regulacje umowne. W pewnym zakresie mogą one także oddziaływać na moment uaktualnienia się odpowiedzialności inwestora, ale jedynie pośrednio, tj. przez ukształtowanie regulacji dotyczącej wymagalności wynagrodzenia w umowie pomiędzy generalnym wykonawcą (wykonawcą) a podwykonawcą.

\section{Literatura}

Białończyk W., Z problematyki umów o podwykonawstwo robót budowlanych, „Monitor Prawniczy" 2008, nr 4.

Damasiewicz A., Umowa o roboty budowlane, Warszawa 2010.

Drapała P., Glosa do wyroku SN z 6.10.2010 r., II CSK 210/10, „Orzecznictwo Sądów Powszechnych" 2012, nr 5, poz. 48.

Drapała P., Umowa o roboty budowlane, „Przegląd Prawa Handlowego” 2003, nr 8.

Dybowski T., System prawa cywilnego, t. 3, cz. 1, Zobowiązania - część ogólna, red. S. Grzybowski, Wrocław-Warszawa-Kraków-Gdańsk 1976.

Gutowski M., Odpowiedzialność inwestora $w$ umowach o roboty budowlane (na tle art. $647^{1} \S 5$ k.c.), „Państwo i Prawo” 2008, z. 2.

Jamka M., Orzechowski K., Zgoda inwestora na umowę generalnego wykonawcy z podwykonawca, „Monitor Prawniczy” 2009, nr 17.

Konik P., Dopuszczalne zarzuty inwestora ponoszacego odpowiedzialność na podstawie art. $647^{1}$ \& 5 k.c. - glosa do wyroku Sądu Najwyższego z 18.02.2016 r., II CSK 215/15, „Glosa” 2017, nr 3.

Konik P., Odpowiedzialność matżonków wspólników spótki cywilnej - jako inwestora - wobec podwykonawców przy umowie o roboty budowlane, w: Status prawny matżonków w spółkach cywilnych $i$ handlowych, red. Z. Kuniewicz, K. Malinowska-Woźniak, Warszawa 2016.

Kostecki B., Uwagi na temat wykładni przepisu art. 647 (1) Kodeksu cywilnego, „Przegląd Ustawodawstwa Gospodarczego" 2004, nr 7. 
Machnikowski P., System Prawa Prywatnego, t. 5, Zobowiazania czesść ogólna, red. E. Łętowska, Warszawa 2006, s. 466.

Strzępka J., Zgoda inwestora na zawarcie umowy o wykonawstwo, „Monitor Prawniczy" 2012, nr 21.

Strzępka-Frania E., Umowy o generalne wykonawstwo robót budowlanych, Warszawa 2010.

Zagrobelny K., Odpowiedzialność inwestora z umowy o roboty budowlane, Warszawa 2013.

Zagrobelny K., w: Kodeks cywilny. Komentarz, red. E. Gniewek, P. Machnikowski, Warszawa 2014.

\title{
ADMISSIBILITY OF THE CONTRACTUAL REGULATION OF THE INVESTOR'S LIABILITY FOR PAYMENT OF REMUNERATION DUE TO THE SUBCONTRACTOR OF THE GENERAL CONTRACTOR AND ITS SCOPE
}

\begin{abstract}
Summary
The article deals with the possibility of contractual shaping of, arising from art. $6471 \S 5$ Civil Code the investor's responsibility for payment of remuneration due to the subcontractor of the general contractor for construction works. Art. $6471 \S 6$ Civil Code Indicates that different contract terms are invalid, but, on the other hand, statutory regulation is very general, which raises the question of whether it is possible to specify it in the contract. Considerations lead to the conclusion that the freedom of contract is narrow and is essentially limited to the issue of clearance between the general contractor and the investor when the latter makes a payment to the subcontractor. It is also possible to regulate the information obligations of the general contractor to the investor in respect of the clearance of the first contractor with the subcontractors.
\end{abstract}

Keywords: the investor's liability for payment of remuneration due to the subcontractor, contractual shaping of the investor's liability, remuneration due to the subcontractor of construction works, investor's scope of responsibility 